\title{
The factors affecting national examination achievement in high schools
}

\author{
Nenden Susilowati *, Sukidjo Sukidjo \\ Universitas Negeri Yogyakarta. \\ J1. Colombo No. 1, Karang Malang, Sleman, Yogyakarta 55281, Indonesia. \\ cempluknenden@yahoo.com \\ * Corresponding Author
}

\section{ARTICLE INFO}

\section{Article History}

Received:

3 January 2020;

Revised:

19 March 2020;

Accepted:

21 March 2020

\section{Keywords}

Intake of students; The national examination; Learning motivation

\begin{abstract}
This research aims to reveal the factors affecting the achievement in the national examination. This study was analytical research. The population in this study totaled 2,243, whereas the amount of the specified sample was 339 students with techniques of stratified random sampling. The population in this study totaled 2, 243, whereas the amount of the specified samples of 339 students with techniques of stratified random sampling. The data collected through a questionnaire, observation, and documentation. The data analysis used the multiple regression model. The research results are as follows, significant: 1.) There is a significant correlation between the intake of students on the national exam results. The value is of $\mathrm{R}$ is $0.740 ; 2$.) There is a significant correlation between the learning motivation of students on the national exam results. The value of $\mathrm{R}$ is $0.406 ; 3$.) There significant is significant. Correlation of the competency of teachers on the National exam results; the value of $\mathrm{R}$ is 0.398 ; 4.) There is a significant correlation of the school environment on the national exam results; the value of $\mathrm{R}$ is $0.366 ; 5$.) There is a significant correlation of the family support on the national is exam results, the value of $\mathrm{R}$ is 0.443 ; and 6) There is a significant correlation of the intake of students' learning motivation, the competence of teachers, school environment, and family support simultaneously on the national exam is results of the results, the value of $\mathrm{R}$ is 0.825 .
\end{abstract}

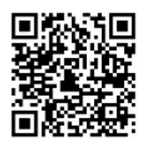

This is an open access article under the $\mathrm{CC}-\mathrm{BY}-\mathrm{SA}$ license.

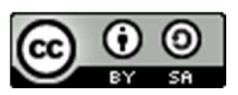

\section{INTRODUCTION}

Life in the era of globalization demands a reliable quality of human resources in order to survive a life full of competition. The business that can be done to realize the quality of human resources that are reliable is through the world of Education (Narwoto \& Suharto, 2013, p. 223). Aware of this, the government's very serious about addressing the education system because with good education expected to emerge the next generation of qualified people both intellectually and morally. One of the ways the government pursued by conducting a National exam. The national Test in Indonesia used as an improvement of the learning process in education or school unit. In-Line with the statement sort Sulistyo (2009, p. 3). The national exam comprises an integral part of a system implemented to improve the quality of national education that has still considered representing a dark side. It further assured that in a curriculum system, the students learning based on the curriculum calls for evaluation. Examinations represent attempts to measure the student's achievement on the pre-stated goes the outlined in the curriculum.

The above opinion can note that the national exam used to measure students' achievements tailored to the objectives outlined in the curriculum. It is a form of accountability while according to 
Christiani (2013, p. 199). Factors that influence the acquisition of national exam values can review from two factors, namely internal and external factors. Internal factors of students are initial ability, student motivation, and student learning, while external factors are: teacher competency, school environment, and family support.

Internal factor that affects students' achievements is their dependence to only hearing their teacher's material and explanation. Students don't experience themselves how to gain concepts, structures, and the principles of the material being taught because their attention transfixed only to the teacher's explanation according to research from Yunita, Sunardi, and Dafik (2013, p. 206). According to Setiawati \& Sudira $(2015$, p. 337) there are influence between students' learning discipline on their learning achievements. Those learning achievements also being influenced by learning. According to Feriady, Harnanik, \& Sunarto (2012, p. 2) learning interest is basically students' interest to study without any compulsion from anyone. According to Berutu and Tambunan (2018, p. 109) factors that affecting the learning outcome are interconnected to one another. Any weaknesses on one of those factors could affect the students' success on learning.

External factors that affect the results of the national exam are that parents should be providing psychological support to students so they are increasingly prepared mentally to face them (Yuzarion, 2017, p. 108). Parents are instrumental in preparing student psychology, as national examinations are the source of anxiety (Anggarawati, 2017). Preparing the student's psychology is influenced by the level of education and employment of the parents (Raharjayanti, 2019, p. 141). These external factors affect students. According to Solehah (2012, p. 19) The onset of anxiety begins with cognitive appraisal against external situations that are considered threatening. The student's anxiety in the face of national examinations should be eliminated, in order to get optimal results. According to Sudiarta, Marhaeni, and Suhandana (2013) in order to achieve optimal results, all quality compensator has to be noticed.

Achievement of success in the learning process can be said optimal when there is a definite synergy between internal factors and external factors. Based on observations in the secondary education office and non-formal Bantul Regency, It can see that the acquisition of the national exam rate of the 2013/2014 academic year for the average value of the economy obtained is 6.64 whereas for the year 2014/2015 decreased to 5.61. The average value in economic subjects is the lowest compared to other subjects. By looking at the acquisition of the average value of the national exam, it can conclude that the results of students studying SMA SE Bantul regency on economic subjects still need to be improved. The results of the national exam in economic subjects in the Bantul Regency are still relatively low and uneven. This fact shows that there are still problems in the process of economic learning. One of the reasons because the majority of high school students in Bantul Regency have The initial ability of students who are still low to influence the outcome of Learning in school. According to Adesoji $(2008$, p. 1) students are not the same, especially when we find out the rate at which facts and principles in sciences assimilated. It is to say that there is a disparity in the ability to perform specific tasks. From opinions, It can be noted that each individual is different from one another, these individual differences were seen in how students learn to solve a problem. Thus the initial ability of students is an initial prerequisite that must be possessed so that the learning process carried out can run well.

As a result of the national exam results of high schools and vocational schools in 2015 total 44,952 in Yogyakarta as many as 13 students were stated not to pass the National exam because the value does not meet the conditions set. Students who do not graduate comprised of eight high school students and five SMK students. Six high school students graduated from Bantul Regency. Besides the early students' ability, other factors influence the acquisition of national exam scores, such as motivation. Motivation plays a crucial role because it can positively move the students' behavior so that it can face all demands, difficulties, and able to bear risk in his studies. According to Brophy (2013, p. 2). Motivation constructs used to explain the initiation, direction, intensity, persistence, and quality of behavior, especially goal-directed behavior. Motives are hypothetical constructs used to explain why people were doing. Doing is doing what they are doing. From these opinions, it can note that motivation used to explain the initiation, direction, inten-sity, persistence, and quality of behavior, especially the behavior directed at the goal. Even motiva-tion can determine whether to achieve goals. Following this opinion, according to Mappeasse (2009, p. 2), from 45 students, 
drained 22 students or about $50 \%$ said that both intrinsic and extrinsic motivation contributes to the acquisition of the results of the final exam in this casein the medium category. Thus, the great motivation that the students have, the higher the success of learning.

Another problem is that the competence of economic teachers, especially pedagogic, and professional competencies are still low. It can see from the teacher competency test results. According to the head of human resources development (Gultom \& Silitonga, 2012, p. 1). The standard minimum value of government-determined teacher competence is 70 , while the data obtained recorded that the national average value of UKG is 42.25 with the number of participants as much as 878,539 . Seeing the results of teacher competency tests that reach an average value of 42.25 , concerns about the ability of teachers to deliver learning are not optimal. In line with this statement according to Komba, Anangisye, and Katabaro (2014, p. 187) the study established that the level of training has primarily influenced the formation of teacher professional identity (TPI) in pedagogy, academic training, and practical experience as an academician. Continuing professional development programs have had little impact because of their sporadic occurrences.

From opinions can be known that the criteria of professional teachers have primarily been influenced by the level of training of K pedagogy, academic training, and practical experience as a researcher. In addition to teacher competency factors, student learning outcomes can also influence school environment factors. School environment factors that are not conducive will impede students in following the learning process at school. For example, some cases involving high school students in Bantul regency, such as the occurrence of juvenile delinquency with the use of molotov cocktails, which happened recently in the district of Sedayu, gave a tremendous impact on the students. So that the case directly affects the comfort of children studying in school. According to Fiskum and Jacobsen $(2012$, p. 39) the educational environment affected the children's behavior in various ways, such as levels of physical activity, concentration, being at ease in the situation, verbal and motor agitation, emotional,expressions, and communication. From this opinion, it can know that the school environment affects children's behavior in various ways, such as the level of verbal, physical activity, and the motor of agitation. From the description, it can conclude that the school environment divided into two, namely physical and non-physical environments. The physical environment is related to school facilities and infrastructures, such as study rooms, library rooms, and lab rooms. In contrast, the non-physical environment includes the relationship between the principal and the teacher, teacher relations with students, and student relations with students.

Based on the results of observations with students, it can seem that the success of students in learning, one of which is influenced by family support. It is undeniable that the family plays an essential role in the daily lives of students. In-line with the Slameto $(2010$, p. 60) opinion, factors that influence family support for student learning outcomes are the way parents educate, relationships among family members, the atmosphere of the home, family economic situation and cultural background. The family is the first and foremost educational institution. A healthy and large family means for education in small sizes, but it is the most relevant for education in the nation, state, and world education. Parental support is thus influential in children's learning outcomes. Based on the results of the observation, it can say that many factors determine the acquisition of national exam scores obtained by students can be both internal and external. Therefore it needs to be considered "The factors affecting achievement national examination in high schools."

In connection with this, the researcher intended to know: 1.) The relation between student initial relationship with the acquisition of national exam results; 2 .) The motivation relationship to study with the acquisition of national exam results; 3.) Relation between teacher competency relationship with the acquisition of national exam results; 4.) The school's environmental relationship with the acquisition of national exam results; 5.) Family support relationship with the acquisition of national exam results; 6.) Relationship between early learning ability of student's motivation study, teacher competence, school environment, and family support together with the acquisition of national exam scores. 


\section{METHOD}

This type of research is an explanatory approach, which explains the causal relationship between the variables of research and tests the hypotheses that have formulated. Design research is associative that examines the cause of causation between two or more profound phenomena. Research have conducted from January to February of the lesson 2015/2016. The population in the study is all students of grade XII IPS in high School in Bantul regency, which amounted to 2.243 students. Sample determination using a stratified random sampling technique. The technique uses to make a complete sample sampling can depict the population thoroughly. Sampling suspended through three stages. First, choose the school by paying attention to the acquisition of average values with the high, medium, low category. Secondly, choice the sampling size with a standard error at $5 \%$ error on the slovin table. Third, using table slovin with a population number of 2.243 obtained the number of sample sizes is 339 .

Schools used as samples in research among another high school in SMA 1 Bantul, SMA 1 Pajangan, SMA 1 Kasihan, and SMA 1 Kretek while for the private is SMA Muhammadiyah Kasihan, SMA Patria, and SMA Muhammadiyah Sewon. The first data collection in this study is used in the following techniques. First, observation is used to seek preliminary information before conducting further research. The preliminary information is a class condition, whether it is a student 's condition, especially the motivation to learn and teaching facilities. Secondly, a questionnaire is a technique of collecting data done by giving a set of written statements or questions to the respondent to answer them. This questionnaire used to measure learning motivation, teacher competence, school environment, and family support. Thirdly, documentation is a systematic process of collecting data so that data is managed and generates a document. Documents obtained from: 1.) The middle and non-formal education fffice in the form of the value of the high school; 2.) Junior High school students; and 3.) National test score in High School; and 4.) Private High School in Bantul Regency from 2013/2014 to 2014/2015.

Before conducting the research, first conducted the instrument test. The Trial results were conducted on two schools with a population of 60 respondents. The results of the instrument trials are as follows. First, the instrument validity test is a measure that indicates the level and validity of an instrument. This validity test uses CFA (Confirmatory Factor Analysis). According to Wagiran (2015, p. 303), the acceptance criteria used in the validity test, if the value of the KMO above 0.50 and the value of probability under 0.05 , then the variable can be analyzed further. The exposure to the test results of the research instruments is as follows: First, the instrument for the variable learning motivation students consists of 20 items statement. According to the criteria of calculation of validity of trials, 5 grains fall, so 15 items are used as research instruments. Secondly, the instrument for the competency variable of the teacher consists of 20 statements. Criteria calculation validity trials are three that fall, so 17 items are used as research instruments. Thirdly, the instrument for the school environment variable consists of 20 items statement. According to the criteria of calculation of validity of trials, 5 grains fall, so there are 15 grains used as a research instrument. Fourth, the instrument for the family support variable consists of 20 items statement. Criteria calculation validity trial is three items fall, 17 grains used research instrument. Secondly, the reliability test relates to the belief in the assay. The condition of reliability of an instrument demands stability, stable, between observations and instruments. They conducted to determine the reliability of research instruments. Cronbach Alpha analysis do the test. According to Azwar (2014, p. 98), this test said to be reliable if the alpha cronbach value equals or greater 0.70 . The exposure of trial instru-ment test results is as follows.

First, the analysis results of the variable trial motivation learned obtained coefficients of Alpha 0.839, it shows that the instrument has high reliability. For this, the instrument has the reliability to measure the variables. Secondly, the analysis test result variable competence teachers acquired coefficient of alpha 0.803 , it shows that the instrument has high reliability. For this, the instrument has the reliability to measure the variables. Thirdly, the analysis test result variable school environment obtained coefficient of alpha 0.807 it shows that the instrument has high reliability. For this, the instrument has the reliability to measure the variables. Fourth, the analysis of family support 
variable trial results obtained coefficient of alpha 0.851 it shows that the instrument has high reliability. For this, the instrument has the reliability to measure the variables.

In the process, the first analysis test prerequisite data analyses. First, the normalities test, which tests whether, in a regression model of dependent variables, the independent variable or both are normal distributions. Secondly, linearities performed to see the absence of a linear relationship between the free variables and the bound variables. Test linearity is done by analyzing variances. The test criterion is if the $\mathrm{F}$ value of the analysis result is higher than the $\mathrm{F}$ value of the table at the significance of $5 \%$, then the effect between the free variables and the bound variables is linear. Thirdly, a multicollinearity test to test if a regression model found a correlation between independent variables. A good regression model should not occur multicollinearity. In the process of analysis, the second was a descriptive analysis. In this study, researchers calculated the average score and standard deviation for each total variable score. The analysis was done on each variable. The trend criteria used in this study refer to the formula that developed by Wagiran $(2015$, p. 337) shown in Table 1.

Table 1. Component Rating

\begin{tabular}{lll}
\hline No. & \multicolumn{1}{c}{ Student Score } & Category \\
\hline 1. & $\mathrm{MI}+1.5 \mathrm{sd}<\mathrm{X}<\mathrm{Mi}+3 \mathrm{SD}$ & Not good \\
2. & $\mathrm{Mi}<\mathrm{X}<\mathrm{Mi}+1.5 \mathrm{SD}$ & Not good \\
3. & $\mathrm{MI}-1.5 \mathrm{SD}<\mathrm{X}<\mathrm{Mi}$ & Good \\
4. & $\mathrm{MI}-3 \mathrm{sd}<\mathrm{X}<\mathrm{MI}-1.5 \mathrm{sd}$ & Excellent \\
\hline
\end{tabular}

In the third process of analysis is a multiple regression analysis used to measure the magnitude of the influence of free variables against variable dependent and predicting variables dependent by using a free variable. If free variables are more than one, then a multiple regression called multiple linear regression, with equations.

$$
\mathrm{Y}=\mathrm{a}+\beta_{1} \mathrm{x}_{1}+\beta_{2} \mathrm{x}_{2}+\ldots \beta_{n} \mathrm{X}_{n}
$$

Description:

$\mathrm{Y}=$ bound variables

$\mathrm{A}=$ number of constants

$\beta_{1}=$ regression coefficient to $X_{1}$

$\beta_{2}=$ regression coefficient to $X_{2}$

$\beta_{n}=$ regression coefficient to $\mathrm{X}_{n}$

In the process of analyzing the fourth data is a contribution relatif. Relative donations used to determine the contribution of each predictor in comparison to the value of criterion. According to Widhiarso $(2008$, p. 4), formula of relative donation calculation is as follows in formula 2.

$$
\mathrm{SR}=\frac{S E}{R^{2}} X 100 \%
$$

Information:

$\mathrm{SE}=$ Effective donation

$R$ Square $=R$ square pada model summary

In the fifth analysis process is the Umbangan give effect used to know the contribution of each predictor in supporting the effectiveness of the regression line for purposes of procurement Predictor. According to Widhiarso (2008, p. 4), the formula of useful donation calculation is as follows in formula 3 . 


$$
\mathrm{SE}=\frac{b X \text { Cross Product } X R^{2}}{\operatorname{Re} \text { gresi }}
$$

Description:

$\mathrm{SE}=$ Effective Donation

$\mathrm{b}=$ Beta

Cross Product $=$ bivariate correlation

$\mathrm{R}$ square $=\mathrm{R}$ Square

Regression $=$ regression calculations

\section{FINDINGS AND DISCCUSIONS}

Once the prerequisite test dilated, then analyzed by using a binary regression to measure the magnitude relation of the variable relationship freely to the variable depends and predicting the dependent variables by using the free variables. Here is the exposure to the results of the analysis of data using multiple regression.

Table 2. Calculation of ANOVA

\begin{tabular}{lccc}
\hline \multicolumn{1}{c}{ Model } & Sum of Squares & F & Sig. \\
\hline Regression & 15120.592 & 141.476 &, $000^{\mathrm{b}}$ \\
Residual & 7118.020 & & \\
Total & 22238.611 & & \\
\hline
\end{tabular}

According to ANOVA in table 2, the above can noted that the F count value of 141.476 is higher than the value of the table $\mathrm{f} 2.210$. It means that the student's initial ability, learning motivation, teacher competence, school environment, and family support have relationships together with the results of the national exam. The significance value $<0.05$, which means there is a student's initial ability relationship, learning motivation, teacher competence, school environment, and family support significantly with national exam results.

Table 3. Coefficients Calculation Results

\begin{tabular}{lccc}
\hline \multicolumn{1}{c}{ Model } & B & Q & Sig. \\
\hline Constant & 29.414 & 11.961 &, 000 \\
Early student skills & 1.005 & 20.184 &, 000 \\
Learning Motivation &, 059 & 8.166 &, 000 \\
Competency Master &, 214 & 7.593 &, 000 \\
School environment &, 068 & 7.212 &, 000 \\
Family support &, 194 & 9.075 &, 000 \\
\hline
\end{tabular}

Based on the results, the calculation can be known as the following research results. First, the distribution of data about the student's initial ability can examine in Figure 1. On the Figure 1 the average score of 339 students who used to sample research 169 students have the intake of students less well. Based on the fact above, it is undeniable that the number of students who have less than proper intake is quite a lot. Therefore, it is necessary to get serious attention from all parties, both parents, community educators, and governments. It is crucial in order to improve the quality of education in Indonesia. Is following the results according to the research of Apjul Ghultom, who said that the students are increasingly high and the breadth of new ability and knowledge of students, thus enlarging the student's opportunity in obtaining better learning outcomes. On the results of multiple regression calculations, It can note that the value of the student's initial ability to calculate a 20.184 value is higher than the value of 2.592, with a signal value of $<0.05$ and an R-value of 0.740 . This means that students' initial ability has a significant relationship with the results of the national exam. 


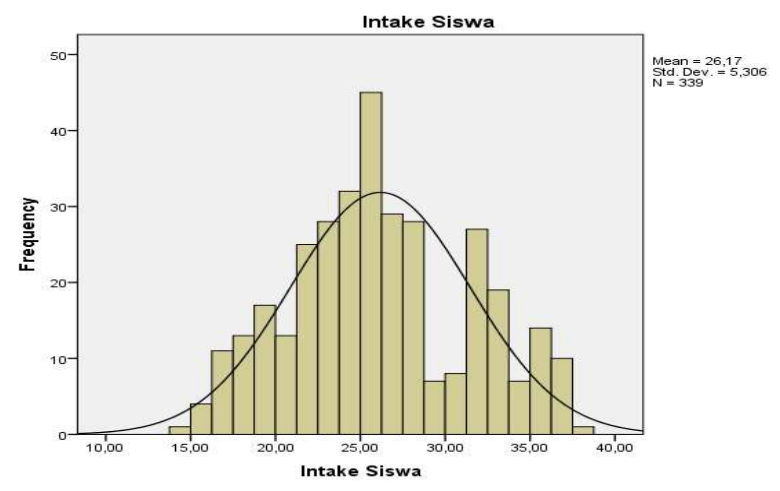

Figure 1. Data Distribution Intake Students

Secondly, the b-based calculation can note that the distribution of data on the motivation to study students could examine in Figure 2. On the Figure 2 the average score of 339 samples and 151 students have a low motivation for learning. Based on the fact, it is undeniable that the low motivation of learning significantly affects the learning process. Motivation is the overall driving force in the students that raises learning activities, which guarantees the continuity of the learning activities and gives direction to the learning activities so that the objectives desired by the learning subjects can achieve. Is following Basuki (2009), the achievement of students in obtaining the value of national exam will be optimal when supported by a positive synergy between the internal factors that are learning subjects that include motivation to study students and active students during the learning process.

On the results of multiple regression calculations, It can note that the value of a learning motivation count of 8.166 that value is higher than the T-table value of 2.592 with significance value $<0,05$ and $\mathrm{R}$-value of 0.406 . This means that the motivation to learn has a significant relationship with the results of the national exam. Third, based calculation results can know that the distribution of data about the competency of teachers can examine in Figure 3.

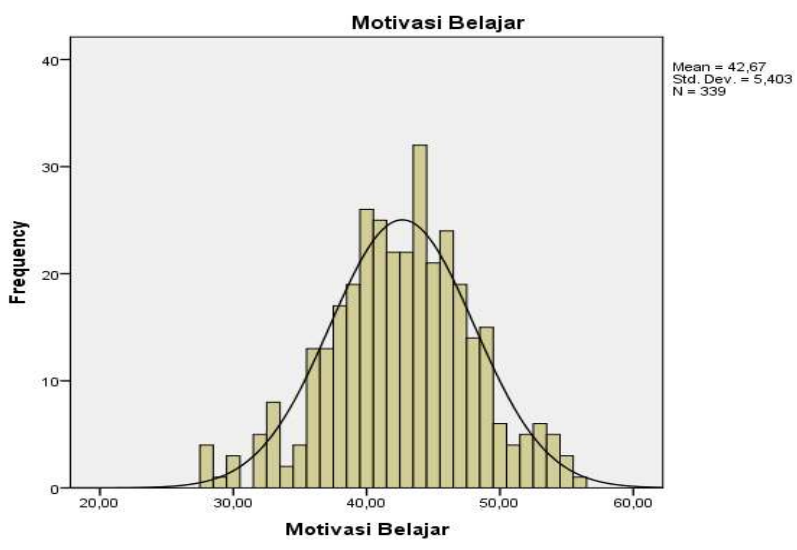

Figure 2. Motivational Data Distribution

On the Figure 3 the average score of 339 students as sample research, there are 147 students have the perception that the competence of teachers high school in Bantul District is still low. Based reality needs to be improved and coaching to the teacher to improve its competence so that it will also affect the quality of teaching. It is in accordance with the research conducted by Djemari Mardapi. In the study, it can know that the factors affecting the results of the national exam, in addition to the students ' factors, also lie in the competency of teachers, especially pedagogic and 
professional. On the results of multiple regression, calculations can note that the value of the teacher's competency count of $7.593<\mathrm{t}_{\text {table }} 2.592$ with a significance value $<0.05$ and an R-value of 0.398 . This means that the competency of the teacher has a significant relationship with the national exam results. Fourth, based calculation results can know that the distribution of data about the school environment can examine in Figure 4.

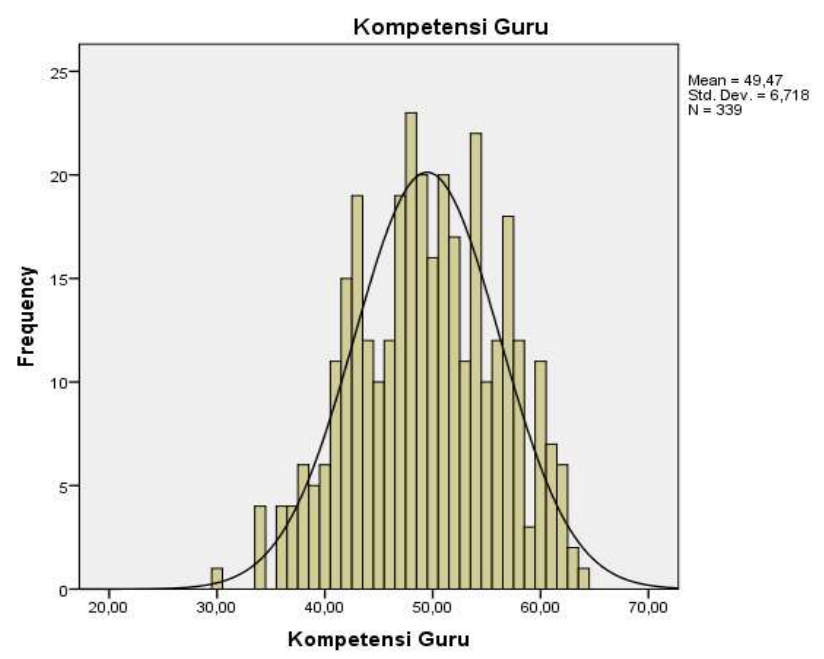

Figure 3. Data Distribution Competency Master

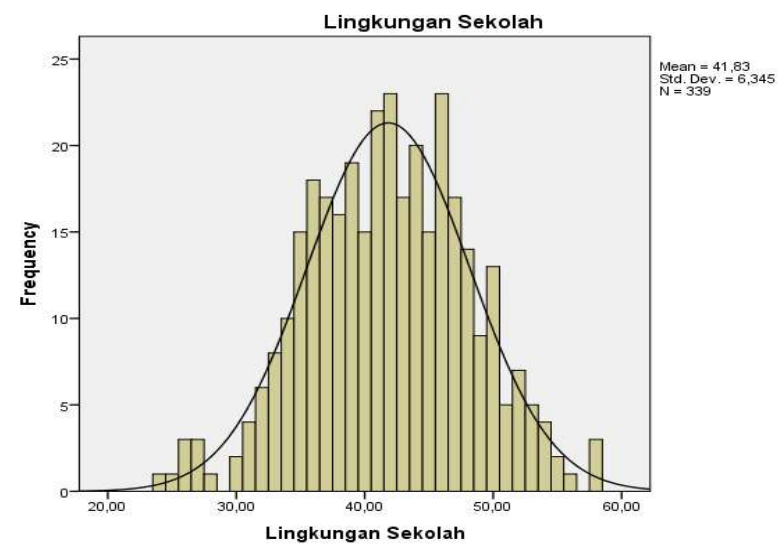

Figure 4. Data Distribution School Environment

On the Figure 4 the average score of 339 students is made samples of research there are 158 students have the perception that the school environment in HIgh School on Bantul District is already good. Given the importance of the school environment in supporting the learning process, there needs to improve the completeness of both physical and non-physical infrastructures that support the learning process. Is following the research conducted by Purnamasari (2013) in the study, it knows that the strategy to improve the results of the national exam on the economic subjects one of them depends on the school environment. Schools can conduct the PPIK program (intra-curricular enrichment program), which is a program designed to help students with difficulties in certain subjects. On the results of multiple regression calculations, it knows that the value of calculating a school environment of 7.212 is greater than that of the higher than the model 2.592 with a value of significance $<0.05$ and an R-value of 0.366. It means that the school environment has a significant relationship with the National exam results.

Based on calculation results can be known that the distribution of data about family support can examine in Figure 5. On the Figure 5 the average score of 339 students as sample research, there 
are 172 students have the perception that the family support is high. Based on the fact, we know that family roles are crucial in the process of learning the students ' activities. So this proves that there is still much.

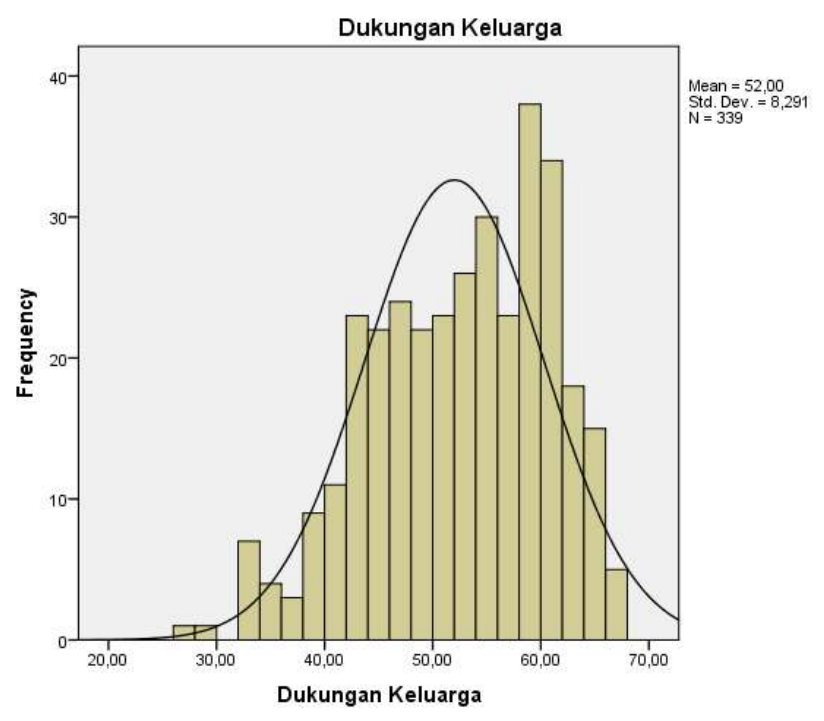

Figure 5. Data Distribution Family Support

improvement to be done to create a comfortable learning environment at home. It is following the research conducted by Basuki (2009) in the study, it is essential to know that the achievement of students in obtaining national exam scores will be optimal when supported by external factors, including parents and social environment. On the results of multiple regression calculations can examine in Table 4.

Table 4. Result of Multiple Regression

\begin{tabular}{clcc}
\hline No. & & Variable & Effective donations \\
\hline 1 & Early student skills & 48.0 \\
2 & Learning Motivation & 7.0 \\
3 & Competency Master & 3.5 \\
4 & School environment & 3.8 \\
5 & Family support & 5.7 \\
& Total & 68.0 \\
\hline
\end{tabular}

The value of the family support calculation of 9.075 is higher than the table T value of 2.592 with a significance value $<0.05$ and an R-value of 0.443 . It means that family support has a significant relationship with the results of the National exam. Thus the equation of the regression line is as follows in formula 4.

$$
\begin{gathered}
Y=29,414+1,005 X_{1}+0,059 X_{2} \\
+0,214 X_{3}+0,068 X_{4}+0,194 X_{5}
\end{gathered}
$$

From the equation of linear regression above, acquired value constants of 29.414. It means if the results of the national exam did not influence by the five free variables or the student intake, motivation study, teacher competence, school environment, and the family support is worth zero, then the average magnitude of the national exam 29.414. If we want to know how much each predictor 's donation in comparison to the value of criterion can see in Table 5. 
Table 5. Value Recap Result Relative Donation

\begin{tabular}{clcc}
\hline No. & & Variable & Relative donation \\
\hline 1 & Early student skills & 70.59 \\
2 & Learning Motivation & 10.29 \\
3 & Competency Master & 5.15 \\
4 & School environment & 5.59 \\
5 & Family support & 8.38 \\
& Total & $100 \%$ \\
\hline
\end{tabular}

From the Tabel 5, it knows that the variable that contributes the most significant contribution to the value of criterion is the student intake of $70.59 \%$ of the dependent variable. If we want to know how much contribution of each predictor in supporting the effectiveness of the regression line for procurement purposes predictor then can be seen in Table 6. From the Table 6 it is known that the variables that make the largest donation in the regres-sion line are the student intake of $48 \%$ against the dependent variable.

Table 6. Value Recap Results Effective Donations

\begin{tabular}{clcc}
\hline No. & & Variable & Relative donation \\
\hline 1 & Early student skills & 48,00 \\
2 & Learning Motivation & 7,00 \\
3 & Competency Master & 3,5 \\
4 & School environment & 3,8 \\
5 & Family support & 5,7 \\
& Total & 68,0 \\
\hline
\end{tabular}

\section{CONCLUSION}

Based on the results of data analysis and discussion, we can be the following conclusion. First, the skills of early High school students in the Bantul District have a relationship that significant with the results of the national exam in economic subjects. Thus the height and breadth of the students' initial ability will increase the likelihood of obtaining better learning outcomes. Secondly, the cultivation of high school students in the Bantul Regency has a significant relationship with the results of the national exam in economic subjects. Therefore, the achievement of students' learning outcomes in obtaining the value of national exams will be optimal when supported by the motivation to learn and active students during the learning process. Thirdly, teacher competence as a significant relationship with the results of the national exam in economic subjects. Thus the factors that affect the results of the national exam, in addition to the internal factors, also lie in external factors such as the competency of teachers focused on pedagogic and professional competence.

Fourth, the school environment has a significant relationship with the results of the national exam in economic subjects. Thus, the school environment plays an essential role in supporting the learning process, so it is necessary to improve the completeness of both physical and non-physical infrastructures that support the learning process. Fifth, family support has a significant relationship with the results of the national exam in economic subjects. Therefore the family must be able to create a comfortable atmosphere to learn. The sense of security and familiarity is also necessary to keep the students feeling so that the students do not experience interference and can affect the concentration of learning. Sixth, students' initial ability, learning motivation, teacher competence, school environment, and family support together have a significant relationship with the results of the national exam in economic subjects. It evidences by the statistical calculations and adjusted to the results of other related studies. Thus the acquisition of national exam scores is said to be useful 
when supported by various aspects. Internal and external aspects that each other complement each other and synergize to achieve the expected objectives.

\section{REFERENCES}

Adesoji, F. A. (2008). Students' ability levels and effectiveness of problem-solving instructional strategy. Journal of Social Sciences, 17(1), 5-8. Doi: https://doi.org/10.1080/09718923.2008.11892628

Anggarawati, D. (2017). Kontrol diri dan kecemasan siswa SMA dalam menghadapi Ujian Nasional (Unpublished bachelor thesis). Universitas Muhammadiyah Surakarta, Indonesia.

Basuki, N. T. (2009). Faktor- faktor yang mempengaruhi ujian nasional pada mata pelajaran matematika di Sulawesi Tengah. Yogyakarta: Program Pascasarjana UNY.

Berutu, M. H. A., \& Tambunan, M. I. H. (2018). Pengaruh minat dan kebiasaan belajar terhadap hasil belajar biologi siswa SMA se-kota Stabat. Jurnal Biolokus: Jurnal of Biological Education and Research, 1(2), 109-115. Doi: http://dx.doi.org/10.30821/biolokus.vli2.351

Brophy, J. E. (2013). Motivating students to learn. United Kingdom: Routledge.

Feriady, M., Harnanik, H., \& Sunarto, St. (2012). Pengaruh persepsi siwa tentang keterampilan mengajar guru dan fasilitas belajar siswa terhadap minat belajar IPS kelas VIII SMP N 3 Purbalingga. Economic Education Analysis Journal, 1(2), 1-7.

Fiskum, T. A., \& Jacobsen, K. (2012). Relation between the school environment and the children's behaviour. The Open Education Journal, 5(1). Doi: https://doi.org/10.2174/1874920801205010039

Ghultom, S. (2012). Nilai rata-rata UKG. Kompas (http://lipsus.kompas.com).

Gultom, A., \& Silitonga, P. M. (2009). Pengaruh kemampuan awal dan model pembelajaran terhadap hasil belajar kimia SMA. Jurnal Pendidikan Matematika dan Sains, 4(2).

Komba, W. L., Anangisye, W. A., \& Katabaro, J. K. (2013). The development of teacher professional identity at the University of Dar es Salaam: Perceptions and influencing factors. Journal of International Cooperation in Education, 15(3), 187-204.

Mappeasse, M. Y. (2009). Pengaruh cara belajar dan motivasi belajar terhadap hasil hasil belajar Programmable Logic Controller (PLC) siswa kelas III jurusan listrik SMK Negeri 5 Makassar. Jurnal MEDTEK, 1(2).

Narwoto, N., \& Soeharto, S. (2015). Faktor-faktor yang berpengaruh terhadap prestasi belajar teori kejuruan siswa SMK. Jurnal Pendidikan Vokasi, 3(2), 222-233. Doi: https://doi.org/10.21831/jpv.v3i2.1603

Purnamasari, D. A. (2013). Strategi meningkatkan hasil ujian nasional mata pelajaran ekonomi. Jurnal Ilmiah Pendidikan Ekonomi IKIP Veteran Semarang, 1(2), 38-48.

Raharjayanti, Y. (2019). Dukungan sosial keluarga dan self efficacy siswa SMP dalam menghadapi Ujian Nasional. Jurnal Promkes: The Indonesian Journal of Health Promotion and Health Education, 7(2), 133-143. Doi: http://dx.doi.org/10.20473/jpk.V7.I2.2019.133-143

Setiawati, L., \& Sudira, P. (2015). Faktor-faktor yang mempengaruhi prestasi belajar praktik kejuruan siswa SMK program studi keahlian teknik komputer dan informatika. Jurnal Pendidikan Vokasi, 5(3), 325-339. Doi: https://doi.org/10.21831/jpv.v5i3.6487

Slameto, S. (2010). Belajar dan faktor yang mempengaruhinya. Jakarta: Rineka Cipta.

Sudiarta, N., Marhaeni, A. A. I. N., \& Suhandana, A. (2013). Kontribusi tingkat intelegensi, nilai Ujian Nasional bahasa Inggris SMP, minat belajar bahasa Inggris terhadap prestasi belajar bahasa Inggris siswa kelas X SMA Negeri 2 Amlapura tahun pelajaran 2012/2013. E-Journal 
Program Pascasarjana Universitas Pendidikan Ganesha Program Studi Administrasi Pendidikan, 4. Doi: https://doi.org/10.23887/japi.v4i1.961

Solehah, L. F. N. (2012). Faktor-faktor penyebab kecemasan siswa dalam menghadapi ujian nasional. Perspektif Ilmu Pendidikan, 25(XVI), 16-32. Doi: https://doi.org/10.21009/PIP.251.3

Sulistyo, G. H. (2015). English as a measurement standard in the national examination: Some Grassroots' voice. Teflin journal, 20(1), 1-24. Doi: http://dx.doi.org/10.15639/teflinjournal.v20i1/1-24.

Wagiran, W. (2015). Metodologi penelitian pendidikan. Yogyakarta: Budi Utomo

Widhiarso, W. (2008). Menghitung sumbangan efektif terhadap variabel dependent. Yogyakarta: Fakultas Psikologi UGM.

Yunita, Y., Sunardi, S., \& Dafik, D. (2013). Identifikasi Faktor Penyebab Rendahnya Penguasaan Materi Dalam Ujian Nasional Matematika SMA/MA program IPA tahun ajaran 2009/2010 di Kabupaten Jember bagian utara dan timur. Pancaran Pendidikan, 2(1), 197-208.

Yuzarion, Y. (2017). Faktor yang mempengaruhi prestasi belajar peserta didik. Ilmu Pendidikan: Jurnal Kajian Teori dan Praktik Kependidikan, 2(1), 107-117. Doi: http://dx.doi.org/10.17977/um027v2i12017p107 